Ankara Üniversitesi Eğitim Bilimleri Fakültesi Dergisi

Yll: 2019, Cilt: 52, Sayl: 3, 915-942

DOI: 10.30964/auebfd.597200, E-ISSN: 2458-8342, P-ISSN: 1301-3718

\title{
Sınıf Yönetiminde Sosyal Adalet ${ }^{1}$
}

\begin{tabular}{lccc}
\hline MAKALE TÜRÜ & Başvuru Tarihi & Kabul Tarihi & Yayın Tarihi \\
Araştırma Makalesi & 26.07 .2019 & 05.11 .2019 & 05.11 .2019 \\
\hline
\end{tabular}

Seval Koçak iD ${ }^{2}$ ve Aynur B. Bostancı

Uşak Üniversitesi

Öz

$\mathrm{Bu}$ araştırma, sosyal açıdan sınırlığı olan (dezavantajlı) öğrencilerin sınıf içerinde yaşadıkları sorunlar temelinde öğretmenlerin sınıf yönetiminde sosyal adaleti sağlama çabalarını belirlemek amacıyla yapılmıştır. Araştırma, nitel araştırma yöntemiyle gerçekleştirilmiştir. Araştırmanın çalışma grubunu, Uşak ilindeki dezavantajlı yerleşim yerlerinde bulunan kamu okullarında görev yapan gönüllü 17 öğretmen oluşturmuştur. Araştırmada veriler, araştırmacılar tarafından hazırlanan yarı yapılandırılmış görüşme formu ile toplanmış ve betimsel analiz ile çözümlenmiştir. Araştırma sonuçlarına göre sınıf yönetiminde sosyal adalet uygulamalarına ilişkin öğretmen görüşleri, dört ana tema altında toplanmıştır. Bu temalar; dezavantajlı öğrencilerin sınıf içi sorunları, öğretmenlerin sınıf içi öğrencilerin yaşadı̆̆ sorunları azaltmak için yaptığı sorunları gidermede sınıf içi uygulamalar, öğretmenlerin sınıf içinde yaptığı uygulamalar önündeki sınırlılıklar ve sınıf yönetiminde sosyal adalet uygulamalarına yönelik okul yönetiminden beklentiler biçiminde oluşmuştur. Yine araştırmanın sonuçlarına göre, öğretmenler, sınıf içinde öğrenci başarısını olumsuz etkileyen velilerden, yönetimden, yasal sınırlılıklardan, okul olanaklarının yetersizliğinden ve zaman yetersizliğinden kaynaklanan sorunlar yaşamaktadırlar. Bu bağlamda okul yönetiminin çeşitli önlemler alması, var olan sınırlayıcı etmenleri ortadan kaldırması beklenmektedir.

Anahtar sözcükler: Dezavantajlı öğrenciler, dezavantajlı okul, sınıf yönetimi, sosyal adalet, sosyal adalet liderliği.

${ }^{1} \mathrm{Bu}$ çalışma 14. Uluslararası Eğitim Yönetimi Kongresinde sözlü bildiri olarak sunulmuş, sadece özet bildiri olarak basılmıștır.

${ }^{2}$ Sorumlu Yazar: Dr., Eğitim Fakültesi, Eğitim Bilimleri Bölümü, Eğitim Yönetimi Anabilim Dalı, E-posta: sevalkocak85@gmail.com, https://orcid.org/0000-0002-9064-2335

${ }^{3}$ Doç. Dr., Eğitim Fakültesi, Eğitim Bilimleri Bölümü, Eğitim Yönetimi Anabilim Dalı, E-posta: aynurbb@gmail.com, https://orcid.org/0000-0002-7927-6063 
Eğitimde sosyal adalet ve demokratik bir toplum bilinci yaratma düşüncesi, giderek artan kültürel çeşitlilik ve sosyal sınıf farklılıkları nedeniyle eğitimcilerin ilgi odağı durumuna gelmiştir. Eğitimde sosyal adaletin önemli bir çalışma alanı olmasında, sosyal bağlamda sınırlı̆ı olan (dezavantajlı) grupların eğitim hakkından diğerleriyle eşit olarak yararlanamaması sonucunda var olan eşitsizliklerin yeniden üretildiğine yönelik söylemler (Apple, çev. 2006; Bourdieu ve Passeron, 1990) etkili olmuştur. Küreselleşmenin etnik köken ve ekonomik düzeyden kaynaklı eşitsizlikleri derinleştirmesi, sosyal adaletin gerekliliğini ve önemini daha da arttırmıştır (Gewirtz, 1998; Zufiaurre ve Wilkinson, 2014). Başka bir deyişle bu süreçte yaşanan hızlı kültürel ve demografik çeşitlenme, eğitimde sosyal adalet konusunu okullar açısından önemli bir çalışma alanı haline getirmiştir (Furman ve Gruenewald, 2004).

Nitelikli eğitime erişimde engel ve sınırlılık yaratan, öğrencileri dezavantajlı duruma düşüren bu sosyal farklılıklar, cinsiyet, dil, etnik köken, sosyo-ekonomik durum, toplumsal kaynaklara ulaşımdaki dengesizlikler, aile yapısı, özel gereksinimli olma gibi özellikler odağında tartışılmaktadır (Archer, Hutchings, Leathwood, ve Ross, 2003; Chiu ve Walker, 2007; Ferreira ve Gignoux, 2010; McWhirter, 1997). Yapılan araştırmalar sosyal farklılıkları nedeniyle dezavantajlı konumda olan öğrencilerin eğitimden eşit düzeyde yararlanamadıklarına, başarı düzeylerinin düşük olduğuna ve sosyal bağlamda başarısız kişilik özellikleri gösterdiklerine işaret etmektedir (Chiu ve Walker, 2007; Çiftçi ve Çağlar, 2014; Enslin, 2006; Sart, Barış, Sarışık ve Düşüun, 2016; United Nations Educational, Scientific and Cultural Organization-UNESCO, 2017). Ayrıca çalışmalar, bu öğrencilerin okula karşı bir bağlılık hissetmediklerini ve okula devam konusunda istekli olmadıkların da göstermektedir (McLaren, çev. 2011).

Sosyal farklılıkları nedeniyle dezavantajlı konumda bulunan öğrencilerin maruz kaldığı olumsuz durumlarla mücadele etmek, sosyal adaleti sağlama çabaları içinde yer almaktadır (Furman ve Shields, 2005). Dolayısıyla eğitimde sosyal adalet, sosyal farklılığı ne olursa olsun tüm öğrencilerin nitelikli eğitim ve öğretimden eşit düzeyde yararlandığı, demokratik ve adil bir eğitim yaşantısı sağlama çabalarını kapsamaktadır. Nitekim Theoharis (2007) eğitimde sosyal adaleti sağlama çabalarını, ötekileştirilmiş öğrenciler başta olmak üzere tüm öğrencilere yarar sağlayacak bir kültür geliştirme, program ve etkinlikleri tüm öğrencilerin eğitim gereksinimlerini karşılayacak biçimde hazırlama temelinde ele almaktadır. Furman ve Shields (2005) ise, öğretmenlerin tüm öğrencilerin hem akademik başarılarının arttırılması hem de demokratik bir toplum bilincinin kazandırılması yönündeki görevlerine vurgu yapmaktadır. $\mathrm{Bu}$ nedenle eğitim-öğretim hizmetlerini doğrudan öğrencilere sağlamakla yükümlü olan öğretmenler, eğitimde sosyal adaleti sağlamada oldukça önemli bir konumda yer almaktadırlar.

Görüldüğü üzere kimi sosyal farklılıkların yarattığı dezavantajlı durumlar, toplumun her kesiminin nitelikli eğitimden yararlanması önünde engel oluşturabilmektedir. Eğitimde sosyal adaletin sağlanması ile öğretmenlerin sunduğu eğitim yaşantısı ve sınıf içi eylemleri arasında önemli bir bağ bulunmaktadır. Nitekim 
Freire (2005), eğitime erişim konusunda dezavantajlı olan ötekileştirilmiş grupların sorunlarına ancak uygulamaya dönük deneyimlerle çözüm üretilebileceğini belirtmektedir. Benzer şekilde Tomul (2009) eğitimde sosyal adaleti, toplumsal yapı nedeniyle belirginleşen dezavantajlı grupların yaşadığı yoksunlaşma olgusunun giderilmesine yönelik eylemsel bir hizmet alanı olarak değerlendirmektedir. Blackmore (2009) ise, sosyal adaletin ancak sınıfsal ayrımcılıkların önüne geçen eylemlerle olanaklı olabileceğini belirterek sosyal adaletin eylemsel bir süreç olması gerektiğine vurgu yapmaktadır. Yapılan bu açıklamalar toplumsal bir dönüşüm sağlayan, dezavantaj yaratan durumları tümüyle ortadan kaldıran, adaleti sağlayan genel düzeyde eylemlere vurgu yapmaktadır.

Eğitim hizmetlerinin odağında olan öğretmenlere de sosyal adaleti sağlama konusunda uygulamaya dönük önemli görevler düşmektedir (Karacan, Bağlıbel ve Bindak, 2015). Bursa ve Ersoy (2016) öğretmenlerle yaptıkları çalışmada, sosyal adaleti sağlamada öncelikle öğretmenlerin kendilerinin rol modeli olarak farklı kültür ve düşüncelere saygı göstermelerinin önemli ve gerekli olduğunu belirlemişlerdir. Benzer şekilde Aronowitz ve Giroux (1991) da öğrenciler arası fark yaratan adaletsiz durumların ortadan kaldırılmasında, sınıf içi uygulamaların demokratikleştirilmesine vurgu yapmışlardır. Bu çerçevede ele alındığında öğretmenlerden sınıf içinde birer sosyal adalet lideri olmalarının beklendiği söylenebilir. Dolayısıyla öğretmenlerin ilk olarak sosyal adaletin ne olduğunu, hangi bileşenlerden oluştuğunu bilmesi ve ona göre davranışlar sergilemesi gerekmektedir.

Sosyal adalet, genel olarak toplumsal sinıflar arasındaki farklılıkların giderilmesi için nimet ve külfetlerin toplumda adil bir şekilde dağıttılması olarak görülmektedir (Sunal, 2011). Ayrıca sosyal adalet anlayışında, malların ya da hizmetin toplumda nasıl dağıtıldığının yanında, tüm sosyo-politik kural ve ilişkileri içine alan geniş bir bakış açısıyla değerlendirilmesinin de önemli görüldüğü bilinmektedir (Young, 1990). Bu bağlamda alanyazında sosyal adaletin dağıtımc1, kültürel ve ilişkisel boyutları bulunmaktadır. Dağıtımcı adalet, var olan kaynakların toplum içindeki bütün gruplara eşit paylaştrılmasına; kültürel adalet yapılan tüm uygulamaların farklı kültürlerle saygı çerçevesinde yürütülmesine ve hiçbir kültürün bir diğerinden üstün olmadığına; ilişkisel adalet ise tüm toplumsal sınıfların kendileri ile ilgili kararlarda söz sahibi olmasına odaklanmaktadır (Gewirtz ve Cribb, 2002). Buradan yola çıkarak sınıfta sosyal adaleti sağlama çabalarının bu üç noktada ele alınması, sınıf yönetiminde sosyal adaletin sağlanması açısından etkili olacaktır. Başka bir deyişle öğretmenler, sınıflarında sosyal adaleti sağlama çabalarında sosyal adaletin tüm boyutlarına odaklanmalı ve duruma bütüncül bir bakış açısıyla yaklaşmalıdır.

Alanyazında eğitimde sosyal adaletin sağlanması için dikkate alınması gereken bileşenler tartışılmıştır. Örneğin, Furman ve Shields (2005) eğitimde sosyal adaleti sağlamak için gereken bileşenleri, (1) bireylerin kültürel değer ve farklılıklarına mutlak saygı, (2) fikirlerin özgürce dile getirildiği, katılımın sağlandığı ve bunun desteklendiği ortam ve (3) ortak yarar sağlama temelinde, ortak seçim ve karşılıklı 
bağımlılık kültürü olarak açıklamıştır. Bununla birlikte Shields (2002) eğitimde sosyal adaletin yalnızca demokratik değerlerle değil bunun yanında akademik başarı açısından da eşitlikçi bir eğitimle ilişkili olduğunu belirtmiştir. Dolayısıyla bu bileşenler, öğretmenlere sınıf yönetiminde sosyal adaleti sağlama bağlamında önemli görevler yüklemiştir. İlgili çerçevede öğretmenlerin demokratik bir ortam yaratma, haksızlıklara karşı eleştirel bir bakış açısı geliştirme, kültürel farklı1ıklara karşı saygı kültürü oluşturma, öğrencilere kendileri ile ilgili kararlarda söz hakkı verme ve öğrencilerin tamamında akademik başarıyı sağlamak için tüm olanakları eşit bir şekilde sunma görevlerinin olduğunu söylemek olanaklıdır. Nitekim Boyles, Carusi ve Attick (2009) toplumsal gelişimin, öğretmenlerin ve liderlerin okullardaki eşitsizlikleri gidermeye yönelik eylemleri yoluyla sağlanacağını ileri sürmüşlerdir. Bu bağlamda dezavantajlı öğrencilerin sınıf içinde yaşadıkları sorunlar temelinde öğretmenlerin sınıflarında sosyal adaleti sağlamaya yönelik uygulamalarının, bu uygulamaları gerçekleştirirken karşılaştıkları engel ve sınırlılıkların ve bu konuda okul yönetiminden beklentilerinin ortaya çıkarılması önemli görülmüștür. Alanyazında öğretmenlerin sosyal adalet uygulamaları, karşılaştıkları engelleri ve okul yönetiminden beklentilerini belirlemeyi amaçlayan bir çalışmaya rastlanamamış olması da bu çalışmanın itici gücünü oluşturmuştur. İlgili çalışmayla gerek karar vericilere gerekse uygulayıcılara sınıf yönetiminde sosyal adaletin sağlanmasına yönelik uygulamalara, sorunlara ve beklentilere yönelik bir kaynak oluşturabileceği düşünülmüştür. Bu çalışmada öğrencilerin sosyal dezavantajlarına karşı öğretmen uygulamalarının ortaya çıkarılması amaçlanmıştır. Araştırmaya katılan öğretmenlerin görev yaptıkları okulların hepsinin kamu okulu olması ve okul çevresinin birbirine yakın özellikler taşıması nedeniyle de öğrencilerin yaşadıkları sosyal dezavantajların benzer olduğu düşünülmüştür. Bu bağlamda araştırmada dezavatajlı öğrencilere yönelik, öğretmenlerin sosyal adalet uygulamalarının genel bir görünümü ortaya çıkarılmaya çalışılmıştır.

Bu araştırmanın amacı dezavantajlı öğrencilerin sınıf içinde yaşadıkları sorunlar temelinde öğretmenlerin sınıf yönetiminde sosyal adaleti sağlama çabalarını ortaya çıkarmak, sınıf içinde öğretmenlerin sosyal adalete yönelik uygulamalarını sinırlandıran etmenleri belirlemek ve bu konuda okul yönetiminden beklentilerini belirlemektir. Bu amaçla aşağıdaki sorulara yanıt aranmıştır:

Öğretmen görüşlerine göre;

1. Dezavantajlı öğrencilerin sınıf içinde yaşadıkları sorunlar nelerdir?

2. Öğretmenler sınıf içinde sosyal adaletin sağlanmasına yönelik ne gibi uygulamalar yapmaktadırlar?

3. Sınıfta sosyal adaletin sağlanması için gerçekleştirilmek istenilen uygulamaların önündeki sınırlılık ve engeller nelerdir?

4. Sınıfta sosyal adaletin sağlanmasında, öğretmenlerin okul yöneticilerinden beklentileri nelerdir? 


\section{Yöntem}

Araştırmanın bu bölümünde çalışmanın modeli, çalışma grubu ve veri toplama aracına yönelik bilgiler sunulmuştur. Bununla birlikte verilerin nasıl toplandığı ve analiz edildiği açıklanmıştır.

\section{Araştırma Modeli}

Öğretmenlerin sınıf yönetiminde sosyal adaleti sağlama çabalarını, bu çabaları sinırlandıran etmenleri ve bu konuda okul yöneticilerinden beklentilerini ortaya çıkarmayı amaçlayan bu çalışma, nitel araştırma yöntemiyle gerçekleştirilmiştir. Nitel araştırmalar bir durumun derinlemesine araştırdığ çalışmalardır (Yıldırım ve Şimşek, 2011). Yapılan çalışmada dezavantajlı öğrencilerin sınıf içi sorunları temelinde, öğretmenlerin sınıf içindeki sosyal adalet uygulamalarına, bu uygulamalara yönelik engellere, sınırlılıklara ve yönetimden beklentilerine yönelik görüşleri alınmıştır.

\section{Çalışma Grubu}

Araştırmanın çalışma grubunu, Uşak ilinde dezavantajlı olarak görülen okul çevrelerindeki devlet okullarında görev yapan, sosyal dezavantajlı öğrencisi olma ölçütünü taşıyan gönüllü 17 öğretmen oluşturmuştur. Tablo 1'de katılımcılara ilişkin bilgiler bulunmaktadir.

Tablo 1

Katılımcılara Yönelik Bilgiler

\begin{tabular}{lcc}
\hline Değişken & Kategori & Frekans \\
\hline Cinsiyet & Kadın & 9 \\
& Erkek & 8 \\
\hline Okul türü & İlkokul & 6 \\
& Ortaokul & 6 \\
& Lise & 5 \\
\hline Okulun bulunduğu bölge & Merkez & 6 \\
& Çevre ilçeler & 11 \\
\hline
\end{tabular}

Tablo 1'de görüldüğü üzere araştırmaya katılan öğretmenlerin dokuzu kadın, sekizi erkektir. Katılımcıların altısı ilkokul, altısı ortaokul ve beşi liselerde görev yapmaktadır. Okulların bulunduğu bölgeler açısından incelendiğinde ise öğretmenlerin altısının merkezde, 11'inin ise çevre ilçelerde çalıştığı görülmektedir.

\section{Veri Toplama Araçları}

Araştırmada veriler, öğretmenlerle yapılan görüşmeler yoluyla elde edilmiştir. Veriler, araştırmanın amacına uygun olacak şekilde araştırmacılar tarafından hazırlanan yarı yapılandırılmış görüşme formu ile toplanmıştır. Görüşme formunun hazırlanmasında belirlenen açık uçlu sorular ile sondaları, alan uzmanlarına danışılarak düzenlenmiştir. Soruların açık ve anlaşılır olup olmadığının belirlenmesi 
için araştırma kapsamı dışındaki beş öğretmenden görüş alınmış ve bu şekilde form asıl uygulamaya hazır hale getirilmiştir. Görüşmelerden önce öğretmenlere dezavantajlı öğrenci ve sosyal adalet kavramları hakkında bilgi verilmiştir. Bu bağlamda sınıflarında dezavantajlı öğrencileri bulunduğunu belirten öğretmenlerle görüşmeler yapılmıştır. Görüş̧me formunda öğretmenlere yöneltilen sorular: "Dezavantajlı öğrencilerinizin sınıf içinde yaşadıkları sorunlar nelerdir?, Sınıf içerisinde sosyal adaletin sağlanmasına yönelik ne gibi uygulamalar yapıyorsunuz?, Sınıfınızda sosyal adaletin sağlanması için gerçekleştirmek istediğiniz uygulamaların önündeki sınırlılık ve engeller nelerdir? ve Sosyal adaletin sağlanmasında, okul yöneticilerinizden neler bekliyorsunuz?" şeklindedir. Beş açık uçlu soru ve sondalarından oluşturulan form, araştırmacılar tarafından birebir görüşmeler yoluyla uygulanmıştır. Görüşmeler sırasında 11 katılımcının görüşü ses kaydına alınmış, ses kaydına izin vermeyen altı katılımcının görüşü ise not edilmiştir. Ö1, Ö2, ... olarak kodlanan katılımcıların ses kayıtları yazıya aktarılmış ve not edilen diğer görüşlerle birlikte analize hazır duruma getirilmiştir.

\section{Verilerin Analizi}

Veriler, betimsel analiz ile çözümlenmiştir. Betimsel analizde veriler önceden belirlenmiş temalar altında çözümlenmekte ve yorumlanmaktadır (Yıldırım ve Şimşek, 2011). Bu araştırmada da toplanan veriler, araştırmanın amacına uygun olacak biçimde araştırmacılar tarafından önceden belirlenen temalar altında çözümlenerek alayazın destekli olacak şekilde uygun alt temalarla sunulmuştur. Verilerin analizinde araştırmacılar tarafından görüş birliğine varılamayan ifadeler üzerinde tartışılmış ve alt temalara son şekli verilmiştir. Oluşturulan alt temalara ilişskin görüşlerin farklı bir uzman tarafından yeniden değerlendirilmesi de sağlanmıştır. Bu iki farklı değerlendirme arasındaki tutarlılığın belirlenmesinde Miles ve Huberman (1994) formülünden yararlanılmıştır. [P = görüş birliği / (görüş birliği + görüș ayrılığı) x 100] formülüne göre yazarlar ve uzman görüşü arasında \% 93'lük bir görüş birliği oranı elde edilmiştir. Verilerin çözümlenmesiyle elde edilen alt temalar, doğrudan alıntılarla desteklenmiştir.

\section{Bulgular}

Sınıf yönetiminde sosyal adalet uygulamalarına ilişkin öğretmen görüşlerinin alındığı bu çalışmada, dört ana temaya ilişkin alt temalar belirlenmiştir. Yapılan betimsel analiz sonucunda elde edilen tema ve alt temalar, Şekil 1'de gösterilmektedir. 


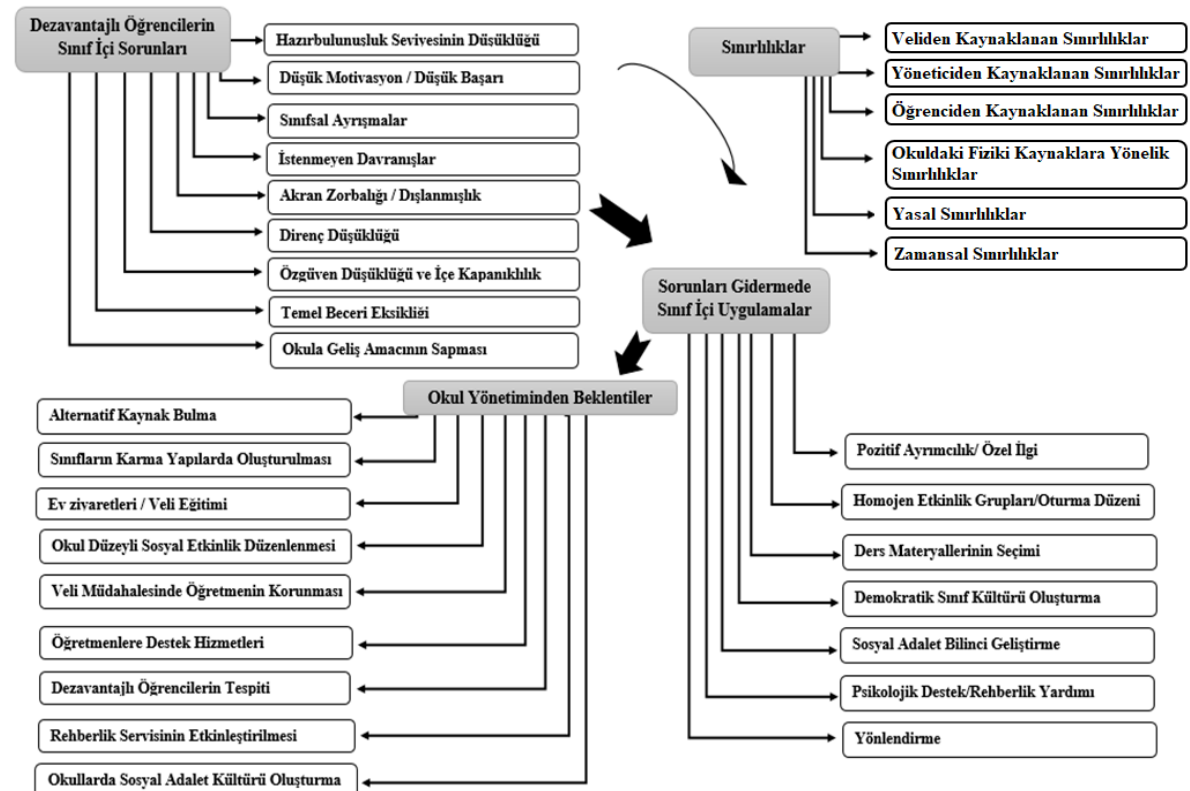

Şekil 1. Verilerin betimsel analizinden elde edilen tema ve alt temalar.

"Dezavantajlı öğrencilerin sınıf içi sorunları" teması, dokuz alt temaya göre incelenmiştir. Bu dokuz alt temaya ilişkin açıklamalar aşağıda sunulmuştur.

“Hazırbulunuşluk seviyesinin düşüklüğü” alt temasında dezavantajlı öğrencilerin hazırbulunuşluk düzeylerinin düşük olduğu, verilen örneklere yönelik önceki yaşantıları veya sosyal deneyimleri olmadığ 1 için anlatılan konuları anlamakta diğerlerine göre daha fazla güçlük çektikleri belirtilmiştir. Bu tema altında Ö6 “(dezavantajlı) öğrencilerin en çok hazırbulunuşluk düzeylerinde bu fark ortaya çıkıyor. Daha önceden edinilmesi gereken bilgilerin yokluğu onu diğer öğrencilerin gerisinde birakiyor. Bu döngü hep böyle gidiyor" ve Ö17 "Bazen bu öğrenciler daha avantajlı olan başarılı çocukların verdikleri örnekleri anlamıyorlar. Çünkü genel olarak daha önce hiç böyle bir şey görmemiş ya da böyle bir deneyim yaşamamış oluyorlar" şeklinde görüş bildirmişlerdir.

"Düşük motivasyon-düşük başarı" alt temasında; dezavantajlı öğrencilerin başarı düzeylerinin, derse katılımlarının ve akademik motivasyonlarının büyük oranda düşük olduğu konularına vurgu yapılmıştır. Buna yönelik olarak Ö5 “Özellikle ekonomik geliri düşük olan öğrencilerde başarı daha düşük oluyor. Çünkü diğerlerinin sahip oldukları imkânlara sahip değiller. Derse katılımları da düşük oluyor" ve Ö9 "Derse katılımda motivasyonları çok düşük, oldukça isteksizler. Kimileri ilgisizlikten, kabullenmişlikten kimileri etkinliklere katılımda gerekli olan malzemeleri alamadığından" biçiminde düşüncelerini belirtmişlerdir. 
“Sınıfsal ayrışmalar” alt temasında öğretmenler, öğrencilerin sosyo-ekonomik düzeylerine bağlı olarak giyim kuşamları ve kullandıkları telefonları, etnik kökenleri ve yaşadıkları kırsal-kentsel bölgeler açısından gruplaşma eğilimine girdiklerini belirtmişlerdir. Bununla birlikte oluşan bu gruplar / sınıflar arasında birbirine üstünlük kurma çabalarına rastlandığını dile getirmişlerdir. Bu bağlamda Ö9 “Öğrenciler arasında giyilen kıyafetler, markalar, cep telefonları, sürülen kokulara kadar bir kıyaslama ortamı çıkabiliyor. Öğrenciler arası sınıflamalara rastlayabiliyoruz”, Ö15 "Köyden gelen taşımalı öğrencilerle kentte oturan öğrenciler arasında ayrışmalar ve kavgalar oluyor. Ama bunlarda velilerin payı var" ve Ö17 "Suriyeli öğrenciler ise dil, din, 1rk farklılıkları nedeniyle dışlanmaktalar.... Daha çok zoraki olarak aynı ortamda bulunmalarının hoşnutsuzluğu var.... Bundan dolayı da sınıf içinde benzer özellikli öğrencilerin gruplaşmaları meydana geliyor ve kutuplaşarak gruplarını soyutluyorlar"demişlerdir.

"İstenmeyen davranışlar" alt teması altında, öğrencilerin dikkat çekmek amacıyla çeşitli taşkın davranışlar içine girdikleri, aileden öyle gördükleri ya da içinde bulunduğu duruma karşı öfke beslediği için şiddete eğilimli olabildikleri, ders sırasında çatışma yaratıp dersin bölünmesine neden olabildikleri ve hırsızlık gibi suçlara eğilimli olabildikleri üzerinde durulmuştur. Bu konudaki görüşlere Ö4 "Dezavantajlı olduğunu düşündüğüm öğrencilerde aşırı alınganlık, yüksek sesle konuşma, dikkat çekme davranışları, çabuk ağlama, geçimsizlik gibi özellikler oluyor.... Arkadaş edinmekte zorlanıyorlar.... Ya da ebeveynlerden birisinin eksikliğini veya aile ilgisizliğini duygusal durumları ile yansitıyorlar” ve Ö16 “Dahası kendi maddi gerçeğini kabul etmeyip hırsızlık yapmayı göze alıyor. Şahsi fikrim kendi adaletini kendi sağlıyor.... O parayla onların sahip olduğu şeyleri almak istemesi ya da onların davranışlarını taklit etmesi” biçiminde örnek vermek olanaklıdır.

“Akran zorbalığı - dışlanmışlık” alt teması altında öğretmenlerin genel olarak dezavantajlı öğrencilerin akran zorbalığına maruz kalabildikleri ve akran zorbalığ yaptıkları üzerinde durulmuştur. Bu konuda Ö3 "Maddi durumu zayıf olan öğrenciler... Akran zorbalığı dışlanma gibi durumlara daha fazla maruz kalabilmektedirler” ve Ö11 “Ailelerinde sözel ya da fiziksel şiddet gören çocuklar aynı şiddeti okulda arkadaşına da uyguluyor. Özellikle erkek öğrencilerin sözel ve fiziksel şiddetleri var, akran zorbalığı yapıyorlar" biçiminde görüşlerini belirtmişlerdir.

“Direnç düşüklüğü” alt temasında dezavantajlı öğrencilerin zorlu bir durum karşısında hemen pes ettiklerine, tekrar deneme gücünü kendilerinde bulamadıklarına, başka bir deyişle yılmazlık düzeylerinin düşük olduğuna dikkat çekilmiştir. Bu tema altındaki görüşlere şu örnekleri vermek olanaklıdır: Ö2 "Dezavantajlı öğrenciler hemen pes etmeye oldukça yatkınlar" ve Ö3 "Öğrenciler başarmaya odaklı değiller. Başarı duyguları olmadığı için hiç çabalamıyorlar bile. Hemen vazgeçiyorlar.”

“Özgüven düşüklüğü ve içe kapanıklılık” alt temasında söz edilen konular, bu öğrencilerin içe kapanık, özgüvensiz, çekingen, sosyal ortamlara girmekte isteksiz ve 
anlamadığını sormada dahi cesaretsiz olduklarına yöneliktir. Bu konuda Ö2 "Bu öğrencilerin çoğu derse katılmada özgüven sorunu yaşıyor. Çekingen kalıyor ve öğrenilmiş çaresizlik geliştiriyor. Anlamadığını sormada cesaretleri olmuyor”, Ö3 "Maddi durumu zayıf olan öğrenciler daha çekingen ve pasif kalıyorlar. Sosyal ortamlarda daha geri planda kalıyorlar.... Ayrıca köylerden gelen öğrenciler genelde yine daha az güvenli oluyorlar. Engelli öğrencilerimiz de sosyal açıdan geri planda kalıyorlar" ve Ö4 "Bu öğrenciler psikolojik olarak içe kapanık oluyorlar, sessiz kalıyorlar. Örneğin gelir düzeyi düşük olan öğrencilerin kantinden hiç bir şey alamadıklarını görüyorum.... Materyal sağlama konusunda da eksik kalıyorlar. Bu da onları olumsuz etkiliyor" diyerek görüşlerini belirtmişlerdir.

"Temel beceri eksikliği" alt temasında dezavantajlı öğrencilerin ailede ya da okul öncesi eğitimde almaları gereken bazı çok temel beceriler yönünden de yetersiz olduğuna dikkat çekilmiştir. Bu öğrencilerin büyüklere saygı, dinleme, küfür etmeme, temizlik gibi günlük yaşam becerilerinde eksik oldukları dile getirilmiştir. Bu tema altında öğretmenlerden Ö4 "Özellikle dezavantajlı ve eğitim seviyesi düşük olan aile çocukları ailede kazanılması gereken temizlik, saygı, küfür etmeme gibi temel becerilerden yoksun" olarak, Ö10 ise "Bu çocuklarda aileden ya da okul öncesinde verilecek olan bazı çok temel beceriler eksik. Öncelikle bunlarla uğraşmak zorunda kalıyoruz" biçiminde görüş bildirmişlerdir.

"Okula geliş amacının sapması" alt temasında ise, ailevi sorunları olan öğrencilerin okulu bir sığınma yeri gibi görmesi; ekonomik durumu elverişli olmayan öğrencilerin barınma gereksiniminin karşılandığı yer olarak algılaması, kimilerinin de okulu zoraki gelinen bir yer olarak değerlendirmesi konuları üzerinde görüş belirtilmiştir. Bu konudaki öğretmen görüşlerine verilebilecek bir örnek şu şekildedir: Ö11 "Velilerin eğitime bakışı çocukların da bakışını etkiliyor. Bazıları sadece vakit geçirmek için sınıfa geliyor. Bazıları ailedeki sorunlardan kaçmak için, bazıları da kışın okul daha sıcak diye."

Araştırmanın bir diğer araştırma sorusuna bağlı olarak öğretmenlerin dezavantajlı öğrencilerin yaşadığı sorunları azaltmak için sınıf içinde yaptığı uygulamalar ortaya çıkarılmıştır. Bu çerçevede "sorunları gidermede sınıf içi uygulamalar" teması, yedi alt tema altında toplanmıştır. $\mathrm{Bu}$ temalar aşağıda açıklanmıştır:

"Pozitif ayrımcılık / özel ilgi" alt teması altında öğretmenlerin dezavantajlı öğrencilerle özel olarak ilgilenmeye çalıştıkları, onları dinledikleri, çalışmalarını fazladan destekleyerek akademik başarılarını arttırmaya çalıştıkları, küçük sorumluluklar vererek kendilerini değerli hissetmesini sağladıkları ve sosyal etkinlilerde onlara öncelik verdikleri görülmüştür. Bu konuda Ö1 "Daha fazla fedakârlık yaparak öğrencilerle birebir ekstra ilgilenerek yapmaya çalışıyorum. Yorucu olsa da en azından onları disiplin suçlarından ve kötü davranışlardan uzak tutmaya çalışıyorum", Ö5 "Özel olarak teneffüste veya boş vakitlerde her firsat bulduğumda bu öğrencilerle özel bir konu olmaksızın sohbet ediyorum. Okul dışında yaptıklarıyla alakalı bir yetişkin gibi konuşulduğunda, öğrencilerin davranışlarında 
olumlu anlamda gelişmeler gözlemleniyor" ve Ö6 "Onlarla daha fazla ilgilenmem gerekebiliyor bazen. Onlara sosyal etkinliklerde öncelik veriyorum" diyerek görüşlerini belirtmişlerdir.

"Homojen etkinlik grupları / oturma düzeni” alt temasına bağlı olarak öğretmenlerin sınıf içindeki takım veya grup çalışmalarına önem verdikleri, bu grupları bireyler arası ötekileştirme yaratmayacak yapıda oluşturdukları, karma olarak oluşturulan bu gruplarda etkileşim ve iletişimi sağlamaya çalıştıkları ve sınıftaki oturma düzenini yine homojen dağılım olacak şekilde belirledikleri ortaya çıkarılmıştır. Bu kapsamda Ö7 "Öğrencilerin oturdukları öğrencileri bu tür gruplaşmaların olmayacağı şekilde oturtuyorum. Kimin kiminle oturacağını kurguluyorum bu gibi durumlarda" ve Ö17 "Bir diğer uygulama farklı öğrencilerden oluşturduğum grup etkinlikleri oluyor. Öğrenciler her ne kadar başta burun kıvırıp grup değiştirme isteklerinde bulunsalar da fikrimin değişmediğini gördüklerinde kabulleniyorlar... Bu kez de grup olarak başarılı olabilmek için dayanışma içinde hareket etmek zorunda kalıyorlar" biçiminde görüş bildirmişlerdir.

"Ders materyallerinin seçimi" alt temasında ise öğretmenlerin ders içi etkinlik materyallerini belirlerken maliyeti de düşündükleri, daha ucuz ve kolay bulunabilir farklı materyaller belirledikleri, kimi zaman kendilerinin karşıladıkları ve kimi zaman da sınıfın toplam havuzundan paylaşım yaptıkları belirlenmiştir. Bu şekilde de parasal açıdan olanağı olmayan öğrencilere örtük bir destek sağlamaya çalıştıkları görülmüştür. İlgili tema kapsamında Ö8 "Ben etkinlik materyallerini seçerken ya çok düşük maliyetli olmasına ya da artık malzemelerden olmasına çok önem veriyorum. $\mathrm{Bu}$ şekilde gücü yetmeyen öğrencilerin katılımını sağlıyorum" ve Ö14 "Ders materyallerinde özellikle kolay ulaşılabilir malzemelerle yapmaya çalışıyorum. Kimi zaman sinıfta kim tarafindan getirildiği belli olmayan bir havuz oluşturup kendim dağıtıyorum" demişlerdir.

"Demokratik sınıf kültürü oluşturma" alt temasına göre öğretmenlerin sınıf içinde oylama veya seçim uygulamalarıyla tüm öğrencileri kararlara katmaya çalıştıkları, kurallara uymayan kim olursa olsun aynı yaptırımı uyguladıkları, tüm düşünceleri dinledikleri ve sınıfa dinlettirdikleri, görev ve etkinlik dağılımını eşit ve açık yapmaya çalıştıkları belirlenmiştir. Bu konuda Ö3 "Sınıftaki uygulamalar ve alınan kararlar ortak alınıyor ve bunların uygulanması sağlanıyor", Ö11 "Tüm öğrencilerin eşit olduğu hissini uygulamalarla veriyorum. Herkese eşit söz hakkı vermeye çok dikkat ediyorum. Sınıfta tüm fikirleri dinliyorum ve dinletiyorum", Ö13 "Sınıf içi bütün durumları seçim ya da oylama yoluyla halletmeye çalışıyorum" ve Ö17 "Derse geç kalan eksi alır diye kural koymuşsam, bu öğrenci kim olursa olsun geç geldiği sürece eksi veriyorum. Herhangi bir öğrencide bu kuralı esnetmiyorum ki öğrenciler de zaten böyle bir durumda 'Geç geldi, eksi vereceksiniz değil mi hocam?' diye hatırlatıyorlar” biçiminde görüş bildirmişlerdir.

"Sosyal adalet bilinci geliştirme" alt temasında, zorbalıkla değil yasal yollarla hak arama, adalet, dürüstlük, eşitlik ve güven gibi değerlerin kazandırılmasına çalışıldığı, bu değerlerin sınıf uygulamalarında kurallar içerisine yerleştirildiği, sosyal 
sorumluluk projeleri ile sosyal adalet bilincinin geliştirilmeye çalışıldığ belirlenmiştir. Bu temaya yönelik verilebilecek örnekler şu şekildedir: Ö2 "Sosyal etkinlikler ve sosyal sorumluluk projeleri düzenleyerek ögrencilere sosyal adaletin önemini anlatmaya çalışıyorum”, Ö11 “Her öğrencinin bir birey olduğunu ve değerli olduğu hissini ve bilincini vermeye çalışıyorum. Zorbalıkla değil, doğru şekilde haklarını aramaları için kimi zaman onları cesaretlendiriyorum” ve Ö13 “Gruplaşma ya da ötekileştire gibi durumları sezdiğim ya da duyduğumda çok ciddi bir tutum gösterip bu sorun çözülmedikçe etkinliğin yapılmayacağını söylüyorum. Kimsenin kimseyi küçümseme ya da dışlama gibi bir hakkının olmadığını örneklerle ifade ediyorum."

"Psikolojik destek / rehberlik yardımı" alt teması altında öğretmenler, dezavantajlı öğrencilerin içinde bulunduğu durum nedeniyle yaşadıkları sorunlarla ilgilendiklerini, onların yanında olarak psikolojik destek vermeye çalıştıklarını, bu konuda rehberlik servisinden yardım aldıklarını belirtmişlerdir. Bu tema kapsamında öğretmenlerden Ö1 "Böyle öğrencilerimin her zaman yanında olduğumu, bir sorun olduğunda bu okulda tüm öğretmenlerin ona destek olabilecekleri konusunda konuşmalar yapıyorum", Ö5 "Yaşadıkları sorunlarla alakalı yaşanmış haberleri onlarla paylaşıp olmuş veya olabilecek problemlere karşı onları uyarmaya, hata yapmalarına engel olmaya çalışıyorum. Psikolojik olarak desteklemeye çalışıyorum" ve Ö11 "Dezavantajlı sorunlu çocuklar için rehberlik servisiyle mutlaka iletişim halinde oluyorum. Onlarla işbirliği yapıyorum” diyerek görüşlerini ifade etmişlerdir.

"Yönlendirme" alt teması altında ise öğretmenler, belirli alanlarda yetenekli olduğuna inandıkları dezavantajlı öğrencileri çeşitli etkinlik ve uygulamalara yönlendirdiklerini, onlara bu konuda rehberlik ettiklerini ve kimi zaman onlarla birlikte bu etkinlikere katıldıklarını belirtmişlerdir. $\mathrm{Bu}$ tema altında Ö2 " $\mathrm{Bu}$ bahsettiğim dezavantajlara sahip öğrencileri okul dışında öğrencilerin katılım gösterdiği etkinliklere ya da eğitimlere yönlendiriyorum. Katılımları için yardımcı oluyorum. Hatta kimi zaman birlikte katılıyorum" şeklinde görüş belirtmiştir.

Araştırmanın üçüncü alt problemi kapsamında dezavantajlı öğrencilerin sınıf içi sorunlarını azaltmada yapılan uygulamalar önündeki "Sınırlılıklar" teması, altı alt tema altında incelenmiştir. Bu alt temalar aşağıda açıklanmıştır.

"Veliden kaynaklanan sınırlılıklar" alt teması altında öğretmenler, dezavantajlı öğrenci velilerinin oldukça ilgisiz olduğunu, çocuklarına yeterli sevgi ve güveni veremediklerini, değişim ve yeni etkinliklere karşı direnç gösterdiklerini ve parasal sorunların aile psikolojisi üzerindeki olumsuz etkilerinin çocuğa yansıdığını dile getirmiştir. Ayrıca sadece dezavantajlı öğrenci velileri değil, aynı zamanda maddi olanakları iyi olan eğitim düzeyi yüksek velilerin de önemli bir sınırlayıcı etkisi olduğu belirtilmiştir. Bu velilerin, maddi durumu kötü, akademik bakımdan başarısız, özel gereksinimli ya da farklı etnik kökene sahip olan öğrencilerle kendi çocuklarının aynı sırada oturmalarına hatta aynı sınıfta bile olmalarına karşı direnç gösterdikleri söylenmiştir. Bu durumda onların sosyal adaleti sağlama çalışmalarında önemli bir sınırlılık olduğu anlaşılmıştır. Veli kaynaklı sınırlılıklar kapsamında öğretmenler şu 
şekilde görüş bildirmişlerdir: Ö3 "Velilerin eğitim düzeyleri düşük. Bunun dışında okulda çocukları düzenlenen faaliyetlerde çok ilgisizler. Onlardan izin gerektiren durumlarda görüşmek bile bazen çok zor oluyor”, Ö6 "Dezavantajlı çocukların aileleri genelde maddi durumları kötü olan öğrenciler. Ama bu sorun olmakla birlikte asıl sorun ailelerin ilgisizliği. Ailede çocuğun kendine ve eğitimine verilen değer çocuğa yansıyor", Ö13 "En önemli etmen veliler. Çünkü sınıf oturma düzeni belirlendikten sonra benim çocuğum onunla oturamaz, beni çocuğum daha iyi gibi, karşı tarafi küçümseyici bir yaklaşıma girebiliyorlar", Ö15 "Taşımalı öğrenciler ve pansiyonlu öğrencilerin velileri okula nadir uğruyor.... Gelir durumu iyi olan veliler de her konuda söz hakkına sahip olduklarını düşünmekte ve aşırı müdahaleci davranıyor. Bunlar çok önemli bir sınırlılık bizim için” ve Ö17 “ 'Şu öğrenci kaynaştırma, çocuğumun onunla oturmasını istemiyorum' diyen velilerle karşılaşıyoruz. Sözde eğitimli dediğimiz veliler bile kendi çocuklarını üstün görüp çocuklarının farklı sosyo-ekonomik çevreden gelen öğrencilerle arkadaşlık yapmalarını istemiyor."

"Yönetici kaynaklı sınırlılıklar" alt temasında öğretmenler okul yöneticilerinin dezavantajlı öğrencilerle ilgilenme konusunda istekli olmadıkları, onlara yeterli zamanı ayırmadıkları, veli müdahale ve isteklerine karşı gelemediklerini belirtmişlerdir. Öğretmenler sosyal adalet uygulamalarında önemli bir sınırlayıcının da dezavantajlı olan öğrencilerin kendisi olduğunu söylemişlerdir. Bu konuda Ö2 'Yöneticiler her zaman bu çocuklar üzerine eğilmiyorlar. 'Yetkilerimiz bu kadar.' diyorlar. Bu doğru olabilir ama isteksizlik de var" ve Ö9 "Yöneticilerin veli isteklerine uygun davranması sınırlayıcı bir etken" diyerek görüşlerini bildirmişlerdir.

“Öğrenciden kaynaklanan sınırlılıklar” teması altında kendinden umudu kesmiş, yaşamdan beklentisi olmayan ve içinde bulunduğu durumdan kurtulamayacağını kabullenmiş öğrencilerin ne yapılırsa yapılsın direnç gösterdikleri ve gelişime direndikleri dile getirilmiş̧tir. Bu bağlamda Ö8 "Öğrencinin maddi olanaklara yönelik değiştiremeyeceği durumların farkında olması ve öğrenilmiş çaresizlik geliştirmiş olması önemli bir sınırlılık. Çünkü durumu kabullenmiş oluyor ve ne yaparsanız yapın durumun düzelmeyeceğini düşünüyor" diyerek kimi zaman öğrencilerin de sınırlayıcı bir etmen olabileceğini belirtmiş̧ir.

"Okuldaki fiziki kaynaklara yönelik sınırlılıklar", sınıf içinde sosyal adaleti sağlamaya yönelik uygulamaların önünde bir diğer sınırlılık olarak görülmüştür. $\mathrm{Bu}$ temaya göre dezavantajlı ögrencileri destekleyecek okul bütçesinin olmaması, bu öğrencilerin parasal sorunlar nedeniyle günlük yaşamda ulaşamayacakları donanımın okulda da bulunmaması önemli bir sınırlayıcı etkendir. Bu konuda Ö1 "Okulun araçgereçleri yetersiz olunca özellikle dezavantajlı öğrencilere bir şeyler yapamıyorsunuz. Maddi durumu iyi olan öğrenciler zaten görüyor bunları. Ama gelir düzeyi düşük olan öğrenciler bunları ailede de göremiyor" ve Ö3 "Okulun öğrencileri farklı etkinliklere katılmalarını sağlayacak gerekli bütçe yok. Aileler de destek olmayınca, onlar için yapacaklarımız sınırlanıyor" diyerek fiziki kaynaklara yönelik sınırlılıkların sosyal adaleti sağlama çabaları önünde bir engel oluşturduğunu belirtmişlerdir. 
"Yasal sınırlılıklar", sosyal adalet uygulamaları önündeki engellerden bir diğeri olarak ortaya çıkmıştır. Bu temaya göre öğretmenler, okul yöneticilerinin kendilerine yardım etmek için yeterli yasal yetkiye sahip olmadıklarını, bir etkinlik ya da uygulama için pek çok yasal işlemi yerine getirmek gerektiğini belirtmişlerdir. $\mathrm{Bu}$ temadaki görüşlere şu şekilde örnekler vermek olanaklıdır: Ö1 "Okul müdürünün de öğretmenin de gerekli desteği sağlayabilmek için gerekli yetkisi de kaynağı da yok" ve Ö3 “Okul müdürünün yetkileri sınırlı. Belirlediğimiz projeleri öyle her zaman hayata geçiremiyoruz. Bir sürü prosedürü yerine getirmek gerek. Bir yerden sonra uğraşmak çok zor oluyor."

“Zamansal sinırlılıklar” alt temasında ise öğretmenler, öğretim programının ve diğer işlerin yoğunluğu nedeniyle bu öğrencilere ayrılması gereken ek zamanı ayıramadıklarını belirtmişlerdir. Bu kapsamda Ö5 "En çok sınırlamanın zamandan kaynaklandığını söyleyebilirim. Ders içi kazanım yoğunluğu, müfredat yetiştirme zorunluluğu, kısa teneffüs araları nedeniyle bu öğrencilere ayrılan zaman çok kısıtlı kalmakta” diyerek bu konudaki görüşünü belirtmiştir.

Araştırmanın son sorusu kapsamındaki “Okul Yönetiminden Beklentiler” teması dokuz alt tema altında toplanmıştır. Bu temalara yönelik açıklamalar aşağıdaki gibidir:

“Alternatif kaynaklar bulma” alt teması altında öğretmenler okul müdürlerinden çevrede bulunan gönüllü kurum ve kuruluşlarla işbirliği içine girmelerini, veli desteği ve okul bütçesi dışında farklı kaynaklar bulmada girişimci olmalarını beklemektedirler. Bu kapsamda öğretmenlerden Ö1 "Okul yöneticileri böyle çocuklar için farklı kurum ve kuruluşlarla yazışabilir. Okulda kaynak yoksa daha farklı kaynak arama yollarına gidebilir” ve Ö14 “Okul yönetiminin gerekli yasal işlemleri yapıp farklı sponsorlar bulma, gönüllü kurumlar ayarlamaları olabilir” diyerek görüşlerini iletmişlerdir.

"Sınıfların karma yapılarda oluşturulması" alt temasında öğretmenler okul yönetiminden sınıfları karma yapıda oluşturmaya büyük önem vermelerini, bu konudaki veli isteklerine bağımlı olmamalarını beklemektedirler. Bu temaya şu şekilde örnekler vermek olanaklıdır: Ö7 “Okul yöneticileri, öğretmene göre ya da veliler o öğretmeni istedi diye öğrenci yazmasın yeter. O zaman sınıflar sosyal sınıflara göre ayrılıyor" ve Ö13 "Velilerin ricaları, aile gelirleri ya da başarı düzeyi doğrultusunda hazırlanan sınıflara son verilmeli. Heterojen sınıflar oluşturulmalı.”

"Ev ziyaretleri / veli eğitimi” alt teması altında öğretmenler, dezavantajlı öğrencilerin evlerine ziyaretler düzenlemek üzere girişimde bulunulmasının, öğrencileri daha iyi anlamak ve çözüm önerileri geliştirebilmek açısından etkili olabileceğini düşünmektedirler. Bu bağlamda okul yönetiminden okul-öğrenci-veli iletişimini sağlayacak çalışmalar yürütmesini ve velilere bu konuda eğitim desteği verilmesi konusunda girişimde bulunmasını beklemektedirler. Bu konuda Ö2 "Ev ziyaretlerinin yapılacağı ekipler kurulabilir. S1k sık veli görüşmeleri ile gereken desteğin sağlanabilir", Ö3 “Özellikle yönetim, öğretmen ile veli arasında bir köprü 
olmalı. Biz ilgisiz velileri sık sık okula getirmekte zorlanıyoruz. Okul yönetimi bu işte yardımc1, hatta itici güç olmalı. Özellikle dezavantajlı ailelerle iletişimde olmalı", Ö4 "Velilere çeşitli eğitimler verilebilir. Bunun için üniversite - okul işbirliği kurulabilir müdür talepleriyle" ve Ö8 "Ailelerin bilinçlendirilmeleri gerekiyor. Maddi olanakları sınırlı olsa da manevi desteklerinin çok şeyi başarmada etkili olabileceği anlatılmalı velilere. Müdürler eğitimler konusunda girişimde bulunsa etkili olabilir” diyerek görüşlerini bildirmişlerdir.

"Okul düzeyli sosyal etkinlik düzenlenmesi” alt teması altında okul yönetiminden beklentiler; özellikle dezavantajlı grupların etkili olabileceği alanlarda sosyal etkinlikler düzenlenmesi, onların bu etkinliklere katılımının sağlanması ve başarı duygularının pekiştirilmesi şeklindedir. Bu temada öğretmenler Ö3 "Okul genelinde öncelikle dezavantajlı ögrencilerin tespit edilmesi ve onların iyi oldukları alanlarda faaliyetler düzenlenebilir. Onlara da başarı duygusunu tattırmak onları kazanmak adına etkili olabilir" ve Ö8 "Dezavantajlı ögrencilerin yeteneklerini ön plana çıkaracak etkinliklere yer verilmeli. Onların katılımı desteklenmeli" şeklinde görüş bildirmişlerdir.

"Veli müdahalesinde öğretmenin korunması" alt teması altında öğretmenler okul yönetiminin, velinin aşırı müdahalesine karşı öğretmenin yanında olması gerektiğini, öğretmeni koruması gerektiğini ve velinin sınıf içi kararlara aşırı müdahalesine karşı ciddi bir tutum içinde olması gerektiğini düşünmektedirler. Bu tema altında ele alınan öğretmen görüşlerine şu şekilde örnekler verilebilir: Ö13 "Okul yönetiminin ilk yapması gereken öğretmenin haklı olduğu her durumda güçlü şekilde savunmak ve yanında olduğunu hissettirmektir. Velinin sınıf içi müdahaleci tavırlarının önüne geçilmeli" ve Ö15 "Okul müdürünün dış baskılar karşısında dik durması ve öğretmenini koruması gerek.”

"Öğretmenlere destek hizmetleri” alt temasında öğretmenlerin dezavantajlı öğrenciler konusunda maddi-manevi desteğin sağlanması konusunda destek istedikleri, özellikle özel gereksinimli kaynaştırma öğrencileri konusunda danışma hizmeti bekledikleri görülmektedir. Bu kapsamda Ö2 "Öğretmenlerin bu konudaki çalışmalarında öğretmenlere danışma ve destek hizmeti sağlanması", Ö6 "Öğretmenler olarak bizlere dezavantajlı öğrenciler için yaptığımız etkinlikler için gereken maddi - manevi desteğin sağlanması gerekiyor. Aksi halde bazı şeyleri tek başımıza gerçekleştiremiyoruz" ve Ö16 "Öğretmenlere destek verilmeli. Özellikle kaynaştırma öğrencileri olan öğretmenler için ... ben çok ihtiyaç duyuyorum" demiştir.

"Dezavantajlı öğrencilerin belirlenmesi” alt temasında öğretmenler, öğrenim yılının en başında dezavantajlı öğrencilere ait verilerin, bu öğrencilerin hangi dezavantajlara sahip olduğunun saptanması ve bunların mutlaka öğretmenlerle paylaşılması gerektiğini vurgulamaktadırlar. Bu kapsamda Ö4 "Dezavantajlı çocukların belirlenmesi, gelişimlerinin tespit edilmesi ve izlenmesi sağlanabilir. Bir de maddi sorunlar yaşayan çocukların ihtiyaçlarının karşılanmasına yönelik çalışmalar yürütülmelidir” ve Ö11 "Öğretim yılının en başında öğrencilere yönelik 
bilgilerin tespit edilmesi ve öğretmenle paylaşılması büyük önem taşıyor bence" şeklinde görüş bildirmişlerdir.

"Rehberlik servisinin etkinleştirilmesi" alt temasında, rehberlik servisinde sadece akademik başarıya değil, sosyal olarak dezavantajlı grupların durumlarıyla da ilgilenilmesi, bu konuya ayrı bir başlık açılması gerektiği üzerinde durulmaktadır. $\mathrm{Bu}$ kapsamda Ö5 "Okul yöneticileri rehberlik servisi ile disiplinli ve koordineli çalışmalı. Çocuğun aile durumunu bize detaylı olarak aktaran çalışmalar umuyoruz. Tesadüfen öğrenmemeliyiz, bilinçli olarak öğrenci durumları hakkında bilgi sahibi olmalıyız" ve Ö11 "Öğretmenlerin rehberlik servisi ile işbirliğinin güçlendirilmesi gerekiyor" diyerek görüşlerini bildirmişlerdir.

"Okullarda sosyal adalet kültürü oluşturma" kapsamında okul yönetiminin etkin birer sosyal adalet lideri olması gerektiğinin altı çizilmektedir. Bu bağlamda okul genelinde tüm bireylerin eşit haklara sahip olduğunun, hiçbir grubun diğerinden üstün olmadığının öğrencilere benimsetilmesinin gerektiği vurgulanmaktadır. Ayrıca öğretmenler, farklılıkların bir zenginlik olduğunun aktarılması ve tüm bu değerlerin yaşam biçimi durumuna getirilmesi için gerekli okul kültürünün oluşturulmasının önemli olduğunu dile getirmişlerdir. Bu kapsamda Ö9 “Okulda tüm öğretmen, öğrenci ve hatta diğer çalışanlar arasında asla ayrım olmadığını, birlikte bir aile olduğumuzu aşılayan bir okul ortamı yaratmalıdırlar" ve Ö17 "Okulda sosyal adalet üzerine farkındalık yaratacak afiş, poster ve sloganlarla bu konuya vurgu yapabilirler” diyerek sosyal adaleti destekleyen bir iklim oluşturmaya vurgu yapmışlardır.

\section{Tartışma, Sonuç ve Öneriler}

$\mathrm{Bu}$ araştırma, dezavantajlı öğrencilerin sınıf içinde yaşadıkları sorunları ve ilgili sorunların giderilmesinde öğretmenlerin sınıfta sosyal adaleti sağlama çabalarını, sosyal adaleti sağlamaya yönelik uygulamaların önündeki sınırlılıkları ve okul yönetiminden beklentilerini belirlemek amacıyla yapılmışıtır. Bu amaç kapsamında sınıf yönetiminde sosyal adalet uygulamalarına ilişkin öğretmen görüşleri dört ana tema altında toplanmıştır. Bu temalar; Dezavantajlı Öğrencilerin Sınıf İçi Sorunları, öğretmenlerin öğrencilerin yaşadığı sorunları en aza indirmek için gösterdiği çabaları belirten Sorunları Gidermede Sınıf İçi Uygulamalar, bu uygulamalar önündeki Sınırlılıklar ve sınıf yönetiminde sosyal adalet uygulamaları önündeki sınırları aşmak için Okul Yönetiminden Beklentiler kapsamında ele alınmıştır.

Araştırmanın ilk temasına ilişkin sonuçlar, dezavantajı öğrencilerin sınıf içinde önemli sorunlar yaşadıklarına işaret etmektedir. $\mathrm{Bu}$ sorunlara ilişkin olarak Dezavantajlı öğrencilerin sınıf içi sorunları temasının altında dokuz alt tema elde edilmiştir. Bu alt temalar, öğrencilerin hazır bulunuşluk seviyesinin düşüklüğü, düşük motivasyon-düşük başarı, öğrenciler arasında sınıfsal ayrışmalar, istenmeyen davranışlar, akran zorbalığı - dışlanmışlık, direnç düşüklüğü, özgüven düşüklüğü ve içe kapanıklılık, temel beceri eksikliği ve okula geliş amacının sapması alt temalarıdır. Ögretmen görüşlerine göre oluşan bu alt temalardan anlaşılacağı üzere öğrenciler, sınıf içinde anlatılan konulara yönelik düşük hazır bulunuşluk düzeylerine sahip 
olmakla beraber, aile desteği, ilgi ve sevgisinden yoksun kalabilmektedir. Bu durumlar, öğrencilerin akademik ve sosyal başarılarına yansımakta, onları temel becerilerden yoksun bırakmaktadır. Bu öğrenciler, sınıf içinde kendini diğerlerinden soyutlayabilmekte, içine kapanabilmekte, öz güveni olmayan bir ruh haline sahip olabilmektedirler. Dolayısıyla istenmeyen davranışlara yönelmekte ya da akran zorbalığına maruz kalabilmektedirler. Özcan, Balyer ve Yıldız (2018) tarafindan dezavantajlı okullarda yapılan araştırmada da bu araştırmayla benzer sonuçlara ulaşıldığı görülmektedir. İlgili çalışmaya göre öğretmenler, dezavantajı öğrencilerin başarısızlığını, öğrencilerin öz güvenlerinin eksikliğine, motivasyon eksikliğine, kendilerine bir amaç belirlememelerine, beslenme yetersizliklerine, sınıf içinde dersle ilgilenmemelerine ve derse hazırlıksız gelmelerine, haksızlığa uğradıklarında kendilerini savunmamalarına, okula devamsızlık yapmalarına, madde kullanımına ve şiddete eğilimli olmalarına bağlamaktadırlar. Bunun yanında alanyazında yapılan çalışmalar da dezavantajlı öğrencilerin bu sorunları yaşadığını destekler nitelikte sonuçlara ulaştığını göstermektedir (Chiu ve Walker, 2007; Çiftçi ve Çağlar, 2014; Komba, 2013; Sart ve diğ., 2016; The Organisation for Economic Co-operation and Development-OECD, 2012).

Araştırmanın başka bir sonucuna göre de sorunları gidermede sınıf içi uygulamalar temasıyla ilgili öğretmen görüşlerinin yedi alt tema altında toplandığı görülmektedir. Bu alt temalar, pozitif ayrımcılık / özel ilgi, homojen etkinlik grupları / oturma düzeni, ders materyallerinin seçimi, demokratik sınıf kültürü oluşturma, sosyal adalet bilinci geliştirme, psikolojik destek / rehberlik yardımı ve yönlendirmedir. Görüşleriyle alt temaların oluşumun sağlayan öğretmenler, dezavantajlı öğrencileriyle özel ilgilenerek onları desteklediklerini, başarılı ve değerli hissetmesini sağladıklarını ve sosyal etkinliklerde onlara öncelik verdiklerini dile getirmişlerdir. Yine öğretmenler, sorunları azaltmak için sınıfta bu öğrencileri ötekileştirmeden tüm öğrencileri kararlara kattıklarını ve etkinliklerdeki görev dağılımını eşit ve açık olarak gerçekleştirdiklerini belirtmişlerdir. Öğretmenler, sınıflarında sosyal adalet bilincini geliştirmek için sınıf içi uygulamalarda sosyal sorumluluk çalışmaları yaptıklarını, rehberlik servisinden de yardım alarak bu öğrencilere psikolojik destek verdiklerini ve başka etkinliklerine yönlediklerini de belirtmişlerdir. Bu yapılan uygulamalardan öğretmenlerin, dezavantajlı öğrencilerle diğer öğrenciler arasında eşitliği sağlamaya, dezavantajlı öğrencilerin eğitimden yararlanmasını destekleyecek olanaklar sunmaya ve bu konudaki sorunları giderebilmeye çabaladıkları görülmektedir. Gürgen (2017) de araştırmasında, dezavantajlı durumda olan öğrencilerin öğrenmesi için yönetici ve öğretmenlerin bu öğrenciler için yaptıkları çeşitli uygulamalar olduğunu ve öğrencilere yönelik eşit davranmaya çalıştıklarını belirtmektedir. Benzer biçimde Özcan ve diğ., (2018) araştırmarında, dezavantajlı öğrencilere yönelik okullarda öğrencilerin başarılarını artırmak için ev ziyaretleri, koçluk, deneme sınavları, ödül verme gibi uygulamalar yapıldığını ortaya çıkarmışlardır. Yapılan bu araştırma sonuçlarının, sözü edilen diğer araştırma sonuçlarıyla uyumlu olduğu anlaşılmaktadır. Yine öğretmenlerin dezavantajlı öğrencilere yönelik uygulamalarının önemi, alanyazındaki çalışmalarda 
da vurgulanmaktadır. Örneğin Tomul'a (2009) göre, eğitimde sosyal adaletin sağlamasında öğrenciyi yaşama hazırlayacak ve sosyalleşmesini sağlayacak eğitim ortamlarının sunulması, bu şekilde de farklılıkların azaltılması gerekmektedir. Karacan ve diğ., (2015) öğrencilerin akademik başarıları için eğitim hizmetinin eşit şekilde sunulması, sosyal ve kültürel yapılarına saygı duyarak demokratik bir sınıf ortamı oluşturulması gerektiğini vurgulamaktadırlar. Gezer (2017) ise eğitim ortamlarında sosyal adaleti sağlama görevi olan öğretmenlerin, öğrencilerin farklılıklarına seslenebilen demokratik bir sınıf kültürü oluşturarak sosyal adaleti sağlamaları gerektiğini dile getirmektedir.

Dezavantajlı öğrencilerin sınıf içi sorunlarını azaltmada yapılan uygulamaların önündeki engeller ise sınırlılıklar teması altında altı alt tema olarak incelenmiştir. $\mathrm{Bu}$ tema altında toplanan alt temalar, veliden kaynaklanan sınırlılıklar, yöneticiden kaynaklanan sınırlılıklar, öğrenciden kaynaklanan sınırlılıklar, okuldaki fiziki kaynaklara yönelik sınırlılıklar, yasal sınırlılıklar ve zamansal sınırlılıklar olmuştur. $\mathrm{Bu}$ tema ve alt temaların oluşumunu sağlayan öğretmen görüşleri incelendiğinde ise öğretmenlerin, velilerinin çok ilgisiz olduğunu, aileye bağlı olumsuz etmenlerin öğrencileri etkilediğini, eğitim düzeyi yüksek velilerin kendi çocuklarıyla dezavantajlı öğrencilerin aynı sınıfta olmalarına direnç gösterdiklerini belirttikleri görülmektedir. Yine öğretmenler okul yöneticilerinin dezavantajlı öğrencilerle olması gerektiği kadar ilgilenmediklerini belirtmişlerdir. Öğretmenler sosyal adalet uygulamalarında önemli bir sınırlayıcının da dezavantajlı öğrencilerinin kendileri olduğunu söylemiş̧lerdir. Bu öğrencilerin, hayattan beklentisi olmayan ve içinde bulunduğu durumdan kurtulamayacağını kabullenmiş bireyler olduklarını; sosyal adalet uygulamalarına ve gelişime direndiklerini dile getirmişlerdir. Bununla birlikte öğretmenlere göre okullarda dezavantajlı öğrencileri destekleyecek bütçe ve fiziksel donanım da bulunmamaktadır. Sosyal adalet uygulamaları önündeki engellerden bir diğeri olarak öğretmenler, okul yöneticilerinin yasal yetkilerinin sınırlılığını görmektedirler. Son olarak da öğretmenler iş yoğunlukları nedeniyle dezavantajlı öğrencilere zaman ayıramadıklarını dile getirerek bunu da bir sınırlılık olarak belirtmişlerdir. Araştırmada öğretmenlerin dezavantajlı öğrencilerin sınıf içi sorunlarını azaltmada yaptıkları uygulamaların önündeki engellere yönelik yapılan diğer araştırmalarda da benzer sonuçlara ulaşıldığı görülmüş̧ür (Kondakçı, Kurtay, Oldaç ve Şenay, 2016; Özcan ve diğ., 2018; Özdemir, 2017; Tomul, 2009). Özdemir (2017) yaptığı araştırmada, okul müdürlerinin orta düzeyde sosyal adalet liderliği davranışları sergilediklerini ve okul müdürlerinin dezavantajlı öğrencilerin okullarda gereksinimlerini istenilen düzeyde karşılayamadıklarını belirlemiştir. Yine Tomul (2009) araştırmasında, eğitimde sosyal adaleti sağlamada karşıllaşılan en büyük engelin okuldaki kaynakların yetersizliği ve toplumun duyarsız davranması olduğunu ortaya çıkarmıştır. Özcan ve diğ. (2018) de yaptıkları araştırmada bu sınırlıkları, okulun öğretim ve etkinlik alt yapısı ile parasal durumunun yetersiz olması, eğitimöğretim altyapısının yetersizliği, okul yöneticilerinin yönetsel becerilerinin yetersizliği ve liderlik yapamamaları temelinde ele almışlardır. Ayrıca dezavantajı 
ortaokullarda, çoğunlukla aile yapılarının bozuk olduğu, ailelerin çocuklarına karşı ilgili ve sevgi dolu davranmadıkları ve şiddet uyguladıkları sonuçlarına ulaşmışlardır.

Kondakçı ve diğ. (2016) Türkiye'de dezavantajlı okulların toplumdan soyutlandıklarını ve çevre desteği alamadıklarını düşünmektedirler. Dolayısıyla alanyazında da dezavantajlı ögrencilere yönelik yapılan uygulamaları kabul etmekle birlikte okul yöneticilerine bu konuda önemli sorumluluklar düştüğü vurgulanmaktadır. Ancak DeMatthews (2014), okullarda bütçe ve zaman yetersizliğinin eğitim ve eşitlik konularındaki çeşitli sorunların sosyal adalet liderliğini neredeyse olanaksız bir görev durumuna getirdiğini belirtmektedir. $\mathrm{Bu}$ bağlamda okullarda öğrenci gruplarının gereksinimlerini karşılayabilmek için sosyal adalet liderliği, müdürler için zorunlu bir alan olarak görülmektedir. Ayrıca okul müdürlerinin, öğretmenlerin de bu yönlerinin gelişiminin desteklemesi gerektiği vurgulanmaktadır. Okullar daha kapsayıcı bir sınıf oluşturmaya çalıştıklarında, veliler ve okul arasında çatışmalar ortaya çıkabilmektedir. Bu gibi durumlarda okul yöneticileri doğrudan velilerin isteklerini yapmak yerine, onları inandırmaya çalışmalıdır. Bunun yanında sosyal adalet lideri olan okul müdürünün görevi, okuldaki eşitsizlik etkilerini en aza indirmek, dezavantajlı öğrencilerin eğitim öğretim sürecinden en iyi şekilde yaralanmalarını ve akademik gelişimlerinin desteklenmesini sağlamaktır (Özdemir, 2017). Okulların dezavantajlı olması, yöneticilerin öğrencileri sürekli izleme, bireysel gereksinimlerini karşılama, akademik başarılarını geliştirmelerine yönelik ek çalışmalar yapmalarını zorunlu kılmaktadır (Özcan ve diğ., 2018). Bu konuda Kondakçı ve diğ. (2016) Türkiye'de okul müdürlerinin sosyal adalete yönelik sorumlulukları bulunduğunu, sorumluluklarının sadece mevzuattaki görev tanımlarıyla sınırlı olmadığını belirtmektedirler. Türkiye'deki gelir dağılımındaki adaletsizliklerin okullara yansıdığını ve okulardaki dezavantajlı öğrencilerin eğitim öğretim sürecinden eşit şekilde yararlanabilmelerinde okul müdürlerine önemli görevler düştüğünü, yasalarda olmasa da okul müdürlerinin örtük görevlerinden olduğunu belirtmektedirler. Nitekim Büyükgöze, Şayır, Gülcemal ve Kubilay (2018) araştımalarında, okul müdürlerinin sosyal adalet liderliği ile öğrenci bağlılığı arasında bir ilişki olduğu sonucuna ulaşmışlardır. Bunların yanında Karakütük, Özdoğan-Özbal ve Günbey (2019) de eğitim kurumlarında sosyal adalet liderliğinin yerine getirilbilmesi için, eğitim sisteminin sosyal adaleti destekleyici bir biçimde yapılandırılması ve politika yapıcılarının tüm öğretim düzeylerinde sosyal adaleti sağlamaya yönelik uygulamalar geliştirmeleri gerektiğini vurgulamaktadırlar.

Araştırmanın son teması olan okul yönetiminden beklentiler teması altında ise, dokuz alt tema bulunmaktadır. Bu alt temaların alternatif kaynaklar bulma, sınıfların karma yapılarda oluşturulması, ev ziyaretleri / veli eğitimi, okul düzeyli sosyal etkinlik düzenlenmesi, veli müdahalesinde öğretmenin korunması, dezavantajlı öğrencilerin tespiti, rehberlik servisinin etkinleştirilmesi ve okullarda sosyal adalet kültürü oluşturma olarak oluştuğu görülmüştür. Öğretmenler bu alt temalara yönelik olarak okul müdürlerinden, dezavantajlı öğrenciler için çevrede bulunan kurumlarla işbirliği yapmalarını ve farklı kaynaklar bulmalarını beklemektedirler. Okulda sınıfları karma yapıda oluşturmaya büyük önem vermelerini istemektedirler. Yine 
dezavantajlı öğrencilerin evlerine ziyaretler düzenlemenin öğrencileri daha iyi tanımak açısından etkili olabileceğini düşünmektedirler. Bunun için okul yöneticilerinin okul-öğrenci-veli iletişimini sağlayacak çalışmalar yürütmesini, özellikle dezavantajlı grupların etkili olabileceği alanlarda sosyal, okul içi etkinlikler düzenlenmelerini beklemektedirler. Öğretmenler, okul yönetiminin öğretmenin yanında olması gerektiğini, öğretmenin her türlü veli müdahalelerinden korunması gerektiğini, dezavantajlı öğrencilere maddi-manevi destek sağlanmasını, bu öğrencilere yönelik danışma hizmeti verilmesini ve her öğrenim yılının başında bu öğrencilere ait verilerin kendileriyle paylaşılması gerektiğini belirtmişlerdir. Ayrıca okul yönetiminin her bir üyesinin birer sosyal adalet lideri olması gerektiğinin altı çizilmektedir. $\mathrm{Bu}$ bağlamda okul genelinde tüm bireylerin eşit haklara sahip olduğunun, hiçbir grubun bir diğerinden daha üstün olmadığının öğrencilere benimsetilmesi gerektiği vurgulanmaktadır. Yine öğretmenler, farklılıklara saygının temel etken olduğu bir okul kültürünün oluşturulması gerektiğini belirtmişlerdir. Öğretmenlerin okul yönetiminden beklentiler teması altında görüşleri yapılan çalışmalarla örtüşmektedir. Bu çalışmalardan birine göre sosyal adalet liderleri, ayrım gözetmeksizin tüm öğrencilerin başarılarının artırılmasını sağlamalıdır. Bununla birlikte, dezavantajlı öğrencilerin kendilerini soyutlanmış hissetmeyecekleri bir topluluk duygusu geliştirmelidirler (Özdemir, 2017). Bu kapsamda dezavantajlı öğrencilerin öncelikle eğitime erişilebilir olmaları sağlanmalıdır. Bu öğrencilerin eğitime erişimi sağlandıktan sonra da eşitsizliklerin giderilmesine yönelik uygulamalar gerçekleştirilmeldir. Başka bir deyişle okulların, tüm öğrenciler için eşitliğin sağlandığı, sosyal refah alanı olması sağlanmalıdır (Taşkın-Alp, 2016). Ayrıca sosyal adaleti sağlamaya yönelik okul yönetimlerince gösterilecek çabalar, dezavantajlı öğrencilere değişik kaynaklar sunmayı, farklılıklarının kabul edilmesini ve öğrenmelerinin önemsenmesini kapsamalıdır (Tomul, 2009).

Tüm yukarıdaki araştırma sonuçları doğrultusunda; öğretmenler, sınıf içinde bu dezavantajları azaltacak uygulamalar yürütseler de velilerden, yönetimden, yasal sinırlılıklardan, okul olanaklarının yetersizliğinden ve zaman yetersizliğinden kaynaklana sınırlılıklar yaşamakta, çeşitli dirençlerle karşılaşmaktadırlar. Bu bağlamda okul yönetiminin çeşitli önlemler alması, var olan sınırlayıcı etmenleri ortadan kaldırması gerekmektedir. Nitekim uluslararası alanyazında okullarda sosyal adalet liderliğinin, okul içi sosyal adaleti sağlamada çok önemli bir etken olduğu belirtilmekte ve eğitim yöneticilerinin yetiştirilmesinde bu konu üzerinde önemle durulmaktadır (Capper, Theoharis ve Sebastian, 2006; McClellan ve Domingues, 2006). Bu araştırma sonucunda sunulabilecek öneriler ise şu şekildedir:

- Okul yöneticileri, öğretmenlerin sosyal adaleti sağlama çabalarının önündeki engelleri onlarla konuşmalı ve her okul kendi özelinde var olan dezavantajlı durumlara ilişkin okul ile veli ve okul çevresi işbirliğinin geliştirilmesi, okul rehberlik birimlerinin etkin çalıştırılması, okul fiziki alanlarının düzenlenmesi gibi önlemler alınmalıdır. Bu kapsamda her okulun kendine özgü stratejik planları olmalıdır. 
- Okul yöneticileri ve öğretmenlerin görev tanımlarıyla ilgili yasal düzenlemelerde sosyal adalet liderliği görevi ile ilgili açıklamalara yer verilmelidir.

- Okul yönetimi karma sınıflar oluşturma konusunda kararlı olmalı ve bu konudaki veli isteklerine olan bağımlılığı azaltabilmelidir.

- Okul yöneticilerine ve öğretmenlere, okulda ve sinıfta sosyal adalet konusunda üniversitelerle işbirliği yapılarak farkındalık kazandırmak amacıyla eğitimler verilmelidir.

\section{Kaynakça}

Apple, M. (2006). Eğitim ve iktidar [Education and power]. (E. Bulut Çev.). İstanbul: Kalkedon Yayınları. (Orijinal kitabın yayım tarihi 1984)

Archer, L., Hutchings, M., Leathwood, C., and Ross, A. (2003). Widening participation in higher education implications for policy and practice. In L. Archer, M. Hutchings, and A. Ross (Eds.), Higher education and social class (pp. 193-220). London: RoutletgeFarmer.

Aronowitz, S., and Grioux, H. A. (1991). Postmodern education. politics, culture, and social criticism. Minneapolis, MN: University of Minnesota Pres.

Blackmore, J. (2009). International response essay leadership for social justice: A transnational dialogue. Journal of Research on Leadership Education, 4(1), 110. Retrieved from https://files.eric.ed.gov/fulltext/EJ875405.pdf

Bourdieu, P., and Passeron J.C. (1990). Reproduction in education, society and culture. London: Sage Publications.

Boyles, D., Carusi, T., and Attick, D. (2009). Historical and critical interpretations of social justice. In W. Ayers, T. Quinn and D. Stoval (Eds.), Handbook of social justice in education (pp.30-43). Newyork, NY: Routledge.

Bursa, S., and Ersoy, A. F. (2016). Social studies teachers' perceptions and experiences of social justice. Eurasian Journal of Educational Research, 64, 319-340. Retrieved from https://www.ejer.com.tr/public/assets/catalogs/en/sercanbursa64.pdf

Büyükgöze, H., Şayır G., Gülcemal. E., and Kubilay, S. (2018) Examining the relationship between social justice leadership and student engagement among high school students. Çukurova Üniversitesi Eğitim Fakültesi Dergisi, 47(2), 932-961.

Capper, C. A., Theoharis, G., and Sebastian, J. (2006). Toward a framework for preparing leaders for social justice. Journal of Educational Administration, 44(3), 209-224. doi: 10.1108/09578230610664814 
Chiu, M. M., and Walker, A. (2007). Leadership for social justice in Hong Kong schools. Jurnal of Educational Administration, 45(6), 724-739. doi: $10.1108 / 09578230710829900$

Çiftçi, Ç. ve Çağlar, A. (2014). Ailelerin sosyo-ekonomik özelliklerinin öğrenci başarısı üzerindeki etkisi: Fakirlik kader midir? International Journal of Human Sciences, 11(2), 154-175. doi: 10.14687/ijhs.v11i2.2914

DeMatthews, D. (2014). Dimensions of social justice leadership: A critical review of actions, challenges, dilemmas, and opportunities for the inclusion of students with disabilities in U.S. Schools. Revista Internacional de Educación para la Justicia Social (RIEJS), 3(2), 107-122. Retrieved from https://pdfs.semanticscholar.org/0dc8/c0fccfa85b7c38826b9609581deb9fb160 41.pdf?_ga=2.232311899.598527801.1572606549-1346174419.1572606549

Enslin, P. (2006). Democracy, social justice and education: Feminist strategies in a globalising world. Educational Philosophy and Theory, 38(1), 57-67. doi: 10.1111/j.1469-5812.2006.00174.x

Ferreira, F. H. G. ve Gignoux, J. (2010). Ĕ̆itimde firsat eşitsizliği: Türkiye örneği (Çalışma Raporu Sayı: 4). http://siteresources.worldbank.org/INTTURKEYINTURKISH/1472541269017398324/22764932/EgitimdeFirsatEsitsizligi.pdf adresinden edinilmiştir.

Freire, P. (2005). Pedagogy of the oppressed (30th ed.). New York, NY: Continuum International Publishing Group Inc.

Furman, G. C., and Gruenewald, D. A. (2004). Expanding the landscape of social justice: A critical ecological analysis. Educational Administration Quarterly, 40(1), 47-76. doi: 10.1177/0013161X03259142

Furman, G. C., and Shields, C. M. (2005). How can educational leaders promote and support social justice and democratic community in schools? In W. A. Firestone and C. Riehl. (Eds.), A new agenda for research in educational leadership (pp. 119-137). New York, NY: Teachers College Press.

Gewirtz, S. (1998). Conceptualizing social justice in education: Mapping the territory. Journal of Education Policy, 13(4), 469-484. doi: 10.1080/0268093980130402

Gewirtz, S., and Cribb, A. (2002). Plural conceptions of social justice: İmplications for policy sociology. Journal of Education Policy, 17(5), 499-509. doi: $10.1080 / 02680930210158285$

Gezer, M. (2017). Öğretimde sosyal adalet inançları ölçeğinin Türkçe uyarlaması. Sakarya University Journal of Education, 7(2), 295-309. doi: 10.19126/suje.335868 
Gürgen, B. (2017). Okullarda sosyal adalet algısının incelenmesi (Yayımlanmamış yüksek lisans tezi). Eskişehir Osmangazi Üniversitesi, Eğitim Bilimleri Enstitüsü, Eskişehir.

Karacan, H., Bağlıbel, M. ve Bindak, R. (2015). Okullarda sosyal adalet ölçeğinin geliştirilmesi. Mustafa Kemal Üniversitesi Sosyal Bilimler Enstitüsü Dergisi, 12(31), 54-68. https://dergipark.org.tr/tr/download/article-file/183435 adresinden edinilmiştir.

Karakütük, K., Özdoğan-Özbal, E. ve Günbey, M. (2019). Sosyal adalet liderliğine ilişkin eğitim yönetimi öğretim üyelerinin görüşleri. Y. Kondakçı, S. Emil ve K. Beycioğlu (Ed.), 14. Uluslararası eğitim yönetimi kongresi tam metin bildiri kitabl içinde (ss. https://drive.google.com/file/d/11tZYa4q2mqv86Snsn6Hc6wQnT9PoAY0a/vi ew adresinden edinilmiştir.

Komba, A. (2013). Are economically disadvantaged children in Tanzania committed to primary schooling? KEDI Journal of Educational Policy, 10(1), 63-82. Retrieved from http://eds.b.ebscohost.com/eds/pdfviewer/pdfviewer?vid=1\&sid=abb37a69c9c7-4b11-b2bd-594721fd575e\%40pdc-v-sessmgr05

Kondakçı, Y., Kurtay, M. Z., Oldaç, Y. İ. ve Şenay, H. H. (2016). Türkiye okul müdürlerinin sosyal adalet rolleri. K. Beycioğlu, N. Özer, D. Koşar ve İ. Şahin (Ed.), Eğitim yönetimi araştırmaları içinde (ss. 353-361). Ankara: Pegem Akademi

McClellan, R., and Dominguez, R. (2006) The uneven march toward social justice: Diversity, conflict, and complexity in educational administration programs. Journal of Educational Administration, 44(3), 225-238. doi: $10.1108 / 09578230610664823$

McLaren, P. (2011). Okullarda yaşam: Eleştirel pedegojiye giriş [Life in schools: An introduction to critical pedagogyin foundations of education ]. (E. Z. Topkaya, G. Erdem, Z. G. Kani, A. Yavuz, M. A. İçbay, M. Tekin ve B. Akyol Çev.). Ankara: Anı Yayıncılık. (Orijinal kitabın yayım tarihi 1989)

McWhirter, E. H. (1997). Perceived barriers to education and career: Ethnic and gender differences. Journal of Vocational Behavior, 50, 124-140. Retrieved from

https://pdfs.semanticscholar.org/e5ab/8ccf44a1fcaa9980436566ea47b1b88dfe5 d.pdf

Miles, M. B., and Huberman, A. M. (1994). Qualitative data analysis. London: Sage.

Özcan K., Balyer, A. ve Yıldız, A. (2018). Ekonomik olarak dezavantajlı bölgelerde görev yapan ortaokul müdürlerinin liderlik davranışları. Mersin Üniversitesi Eğitim Fakültesi Dergisi, 14(2), 532-547. doi: 10.17860/mersinefd.434775 
Özdemir, M. (2017). Sosyal adalet liderliği, okula yönelik tutum ve okul bağlılığı arasındaki ilişsilerin incelenmesi. Eğitim ve Bilim, 42(191), 267-281. doi: 10.15390/EB.2017.6281

Sart, Z. H., Barış, S., Sarıșık, Y. ve Düşkün, Y. (2016). Engeli olan çocukların Türkiye'de eğitime erişimi: Durum analizi ve öneriler. İstanbul: ERG.

Shields, C. M. (2002). Social justice and academic excellence. BCAdminfo, 15(6), 810.

Sunal, O. (2011). Sosyal politika: Sosyal adalet açısından kuramsal bir değerlendirme. Ankara Üniversitesi SBF Dergisi, 66(3), 283-305. doi: 10.1501/SBFder_0000002223

Taşkın-Alp, Y. (2016). Öğrenciler ve eğitime erişim. http://www.egitimreformugirisimi.org/wpcontent/uploads/2017/03/EIR201516_ArkaPlanRaporu_OgrencilerveEgitimeErisim_YTA_0.pdf adresinden edinilmiştir.

The Organisation for Economic Co-operation and Development. (2012). Equity and quality in education: Supporting disadvantaged students and schools. Retrieved from http://www.oecd.org/education/school/equityandqualityineducationsupportingdisadvantagedstudentsandschools.htm

Theoharis, G. (2007). Social justice educational leaders and resistance: Toward a theory of social justice leadership. Educational Administration Quarterly, 43(2), 221-258. doi: 10.1177/0013161X06293717

Tomul, E. (2009). İlköğretim okullarındaki sosyal adalet uygulamalarına ilişkin yönetici görüşleri. Eğitim ve Bilim, 34(152), 126-137. http://egitimvebilim.ted.org.tr/index.php/EB/article/view/597/77 adresinden edinilmiştir.

United Nations Educational, Scientific and Cultural Organization. (2017). Accountability in education: Meeting our commitments (Global Education Monitoring Report 2017/8). Paris: UNESCO Publishing. Retrieved from http://unesdoc.unesco.org/images/0025/002593/259338e.pdf

Yıldırım, A. ve Şimşek, H. (2011). Sosyal bilimlerde nitel araştırma yöntemleri. Ankara: Seçkin Yayıncılık.

Young, I. M. (1990). Justice and the politics of difference Princeton. New Jersey, NJ: Princeton University Press.

Zufiaurre, B., and Wilkinson, J. (2014). School leadership: Is a shift from efficient management to social justice possible? Enero, 53(1), 114-129. Retrieved from https://pdfs.semanticscholar.org/5690/d734ec9315d7d57528fac9dc72b43fa2a8 30.pdf?_ga=2.166825210.598527801.1572606549-1346174419.1572606549 


\section{Social Justice in Classroom Management ${ }^{1}$}

\begin{tabular}{cccc}
\hline $\begin{array}{c}\text { ARTICLE TYPE } \\
\text { Research Article }\end{array}$ & $\begin{array}{c}\text { Received Date } \\
07.26 .2019\end{array}$ & $\begin{array}{c}\text { Accepted Date } \\
11.05 .2019\end{array}$ & $\begin{array}{c}\text { Published Date } \\
11.05 .2019\end{array}$ \\
\hline Seval Koçak & \multicolumn{2}{c}{${ }^{2}$ and Aynur B. Bostanci } \\
Usak University
\end{tabular}

\section{Abstract}

The aim of this study was to determine the problems that disadvantaged students have in the classroom and teachers' efforts to ensure social justice in classroom management. The research was carried out with a case study design, one of the qualitative research methods. The study group consisted of 17 volunteer teachers working in public schools in Uşak. Data were collected by a semi-structured interview form prepared by the researchers and analyzed by descriptive analysis. According to the results of the study, teachers' opinions about social justice practices in classroom management were gathered under four main themes. These themes are in-class problems of disadvantaged students, classroom practices in resolving problems, limitations obstacles for teachers about the practices in the classroom and expectations from school management regarding social justice practices in classroom management. According to the research, although teachers carry out practices to reduce these disadvantages in the classroom, they have problems arising from parents, administration, legal limitations, lack of school facilities and lack of time. In this context, the school administration is expected to take various measures and eliminate existing limiting factors.

Keywords: Disadvantaged students, disadvantaged school, classroom management, social justice, social justice leadership.

\footnotetext{
${ }^{1}$ This article was presented at the $14^{\text {th }}$ International Congress on Educaitonal Administration and published only as an abstract paper.

${ }^{2}$ Corresponding Author: PhD., Faculty of Education, Departmant of Educational Administration, E-mail: sevalkocak85@gmail.com, https://orcid.org/0000-0002-9064-2335

${ }^{3}$ Assoc. Prof. PhD., Faculty of Education, Departmant of Educational Administration, E-mail: aynurbb@gmail.com, https://orcid.org/0000-0002-7927-6063
} 


\section{Purpose and Significance}

Social justice in education and the idea of creating a democratic society consciousness have become the focus of the attention of educators due to the increasing cultural diversity and social class differences. The discourse that reproduces existing inequalities as a result of the fact that disadvantaged groups cannot benefit from the right to education on an equal basis in social context (Apple, trans. 2006; Bourdieu and Passeron, 1990) was effective in social justice is an important field of study. The deepening of inequalities stemming from ethnicity and economic level of globalization has further increased the necessity and importance of social justice (Gewirtz, 1998; Zufiaurre and Wilkinson, 2014). In other words, the rapid cultural and demographic diversification in this process has made the issue of social justice in education an important field of study for schools (Furman and Gruenewald, 2004). Struggling with the damaging effects of students who are disadvantaged due to their social differences is involved in efforts to ensure social justice (Furman and Shields, 2005). Therefore, social justice in education includes efforts to ensure a democratic and fair educational experience in which all students, regardless of their social differences, benefit equally from qualified education and training. According to Furman and Shields (2005), social justice emphasizes the role of teachers in increasing the academic achievement of all students and raising awareness of a democratic society. Therefore, teachers, who are obliged to provide education services directly to the students, play an important role in ensuring social justice in education.

The aim of this study is to reveal the efforts of teachers to ensure social justice in classroom management on the basis of the problems experienced by disadvantaged students in the classroom, to determine the factors that limit the practices of teachers towards social justice in the classroom and to determine their expectations from the school administration. For this purpose, the following questions were sought:

According to the views of teachers;

1. What are the problems that disadvantaged students have in class?

2. What practices do teachers do to ensure social justice in the classroom?

3. What are the limitations and barriers to the activities to be carried out to ensure social justice in the classroom?

4. What are the expectations of teachers from school administrators in ensuring social justice in the classroom?

\section{Method}

This study has been carried out by qualitative research method. In the study, on the basis of classroom problems of disadvantaged students, teachers' opinions about social justice practices in the classroom, obstacles and limitations to these practices and their expectations from management were taken. The study group was composed 
of 17 volunteer teachers working in public schools in Uşak. Data were collected with a semi-structured interview form prepared by the researchers in accordance with the purpose of the study. The data were analyzed by descriptive analysis. In this study, the data were analyzed under the main themes determined in accordance with the purpose of the research and appropriate sub-themes were determined. In the analysis of the data, the expressions which could not be reached a common agreement were discussed again and sub-themes were finalized. The sub-themes obtained from the analysis of the data were supported by direct citations.

\section{Results}

According to the results of the study, teachers' opinions about social justice practices in classroom management were gathered under four main themes. These themes are "In-Class Problems of Disadvantaged Students", "Classroom Practices in Resolving Problems", which teachers made in order to minimize the problems experienced by in-class students," Limitations" obstacles for teachers about the practices in the classroom and "Expectations from School Management" regarding social justice practices in classroom management.

The results of the first theme of the study, in-class problems of disadvantaged students, indicate that disadvantaged students experience considerable problems in the classroom. These sub-themes are: "Low level of readiness of students," "Low motivation-low achievement", "Class differences among students", Undesired behaviors", "Peer bullying-exclusion", "Low resistance", "Low self-esteem and introversion ", "Lack of basic skills" and "Deviation of purpose of attending school". The second theme of the study is that teachers' opinions about the theme of classroom practices in solving problems are gathered under seven sub-themes. These sub-themes are "Positive discrimination / special attention", "Homogeneous activity groups / seating arrangement", "Selection of course materials", "Creating democratic class culture", "Social awareness raising", "Psychological support / guidance assistance" and "Guidance". Six sub-themes were created under the theme limitations, which is the third theme for the obstacles to the practices in reducing the classroom problems of disadvantaged students. These sub-themes are "Parent-borne limitations", "Administrator-borne limitations", "Student-borne limitations", "Physical resources in school", "Legal limitations" and "Temporal limitations". Under the fourth and last theme of the research, expectations from school administration, there are nine subthemes. "Finding alternative sources", "Creating classes in mixed structures ", "Home visits / parent education", "Organizing school-level social activities", "Protection of teachers in parent intervention", "support services for teacher", "Identifying disadvantaged students", "Enabling guidance service" and "Creation of social justice culture in schools"

\section{Discussion and Conclusions}

The results of the first theme of the study, in-class problems of disadvantaged students, indicate that disadvantaged students experience considerable problems in 
the classroom. According to the teachers' views, students may have low levels of readiness for the topics described in the classroom but they may be deprived of family support, interest and love. These situations are reflected in the academic and social achievements of the students and deprive them of basic skills. These students may isolate themselves from others, to be withdrawn, to have a lack of self-confidence mood. Özcan, Balyer and Yildiz (2018) have reached similar conclusions about the problems experienced by students in their research. In addition, the studies conducted in the literature support that disadvantaged students experience these problems (Chiu and Walker, 2007; Çiftçi and Çağlar, 2014; Komba, 2013; The Organisation for Economic Co-operation and Development-OECD, 2012; Sart, Barış, Sarışık and Düşkün, 2016).

According to another result of the study, teachers who provide the formation of the theme of classroom practices in solving problems stated that they support their disadvantaged students with special care, make them feel successful and valuable and give them priority in social activities. The teachers also stated that in order to reduce the problems, they included all the students in the decisions without marginalizing these students in the classroom and they carried out the task distribution in the activities fairly and transparently. The teachers also stated that they carried out social responsibility activities in the classroom practices in order to develop social justice awareness in their classrooms, they also provided psychological support to these students by taking help from the guidance service and directed them to other activities. From these practices, it is seen that teachers strive to ensure equality between disadvantaged students and other students and to ensure that disadvantaged students can benefit from education and to solve their problems. Gürgen (2017) and Özcan et al. (2018) are consistent the reaults with the results of their research and are supported. Again, the practices of teachers towards disadvantaged students are consistent with the studies in the literature (Gezer, 2017; Karacan, Bağlıbel and Bindak, 2015; Tomul, 2009)

According to the theme of limitations the barriers to the practices of the disadvantaged students in reducing the classroom problems, teachers' views can be summarized as follows. The teachers stated that their parents were very indifferent, that the negative effects of the family affected the students and that the parents with a high educational level resisted their children being in the same class with the disadvantaged students. Again, teachers stated that school administrators were not interested in disadvantaged students. The teachers stated that the students who were disadvantaged were an important limitation in social justice practices. They stated that these students resisted the structures and developments, had no expectation from life and accepted that they could not get out of the situation. According to teachers, schools do not have a budget and physical equipment to support disadvantaged students. Teachers see the legal powers of school administrators as one of the obstacles to their social justice practices. Finally, teachers stated that they could not allocate time to disadvantaged students because of their work intensities. In the study, it was observed that similar results were obtained in the other studies conducted by 
Özdemir (2017), Tomul (2009), Özcan et al. (2018) and Kondakçı, Oldaç and Şenay (2016). In the literature, although it accepts practices for disadvantaged students, it emphasizes that school administrators have responsibility for this issue (Büyükgöze, Sayır, Gülcemal and Kubilay, 2018; DeMatthews, 2014; Kondakçı et al., 2016; Özdemir, 2017; Özcan et al., 2018).

For the last theme of the research, in theme of expectations from school management, teachers expect school principals to cooperate with the institutions in the vicinity and find different sources for disadvantaged students. They want them to attach great importance to forming classes in a heterogeneous structure. They also think that organizing visits to disadvantaged students' homes may be effective in getting to know the students better. To this end, they expect the school administrators to carry out studies to ensure school-student-parent communication and organize social in-school activities, especially in areas where disadvantaged groups can be effective. The teachers stated that the school management should be with the teacher, that the teacher should be protected from all kinds of parents' interventions, that the disadvantaged students should be provided with financial and moral support, that these students should be consulted and that the data of these students should be shared with them at the beginning of each academic year. They also underline that each member of the school administration should be a leader of social justice. In this context, it is emphasized that all individuals have equal rights throughout the school, and that no group is superior to the other, and that students should be adopted. In addition, the teachers stated that it is necessary to create the necessary school culture in order to instill the differences as wealth and to transform all these values into lifestyles. The theme of expectations of teachers from school management coincides with the literature (Özdemir, 2017; Taşkın-Alp, 2016; Tomul, 2009).

In line with all the above research results; although teachers carry out practices to reduce these disadvantages in the classroom, they have problems arising from parents, management, legal limitations, lack of school facilities and lack of time. In this context, the school management should take various measures and eliminate the existing limiting factors. 